\title{
Statins: What is Beyond Hyperlipidemia?
}

\author{
Marianne L Shahsuvaryan* \\ Yerevan State Medical University, Armenia \\ Submission: March 03, 2017; Published: March 27, 2017 \\ *Corresponding author: Marianne L Shahsuvaryan, Yerevan State Medical University, Armenia, Tel: (374 10) 5234 68; \\ Email: mar_shah@hotmail.com
}

\section{Opinion}

Statins are the most commonly used lipid lowering drugs [1]. Recent experimental evidence underscores additional cholesterol independent or pleiotropic effects, contributing to prevention and inhibition of atherosclerosis. These vascular pleiotropic effects include amelioration of endothelial function, the inflammatory process retardation, the thrombus formation blockage, increase of plaque stability and decreasing oxidative stress [2]. Thus, currently statins are believed to be as one of the most powerful drugs for the treatment of vascular disease $[3,4]$. The treatment of endothelial dysfunction in chronic cardiovascular diseases is already evidenced.

Keeping in mind the uniformity of the vascular system physiologically and pathophysiologically, and that it plays a key role in age-related macular degeneration (AMD), endothelial dysfunction should be treated [5,6]. Age-related macular degeneration is a progressive late onset disease affecting central vision, representing the leading cause of irreversible blindness among older adults, affecting one in three people aged 75 or older, and with the aging population the problem is increasing $[7,8]$.

The estimated number of patients suffered from age-related macular degeneration will increase by $50 \%$ by the year 2020 [9]. At present effective treatment for AMD or for arresting its progression in its earliest phases does not exist. There is a growing body of epidemiologic, genetic, pathological evidence suggesting a possible link between risk factors for cardiovascular disease and age-related macular degeneration, thus highlighting the rationale behind statins use.

Statins decrease serum lipid levels, and accumulation of lipids in the Bruch membrane and drusen, which is a key pathophysiologic pathway for AMD development [10]. Another mechanisms of action for statins in AMD are oxidative damage and inflammation diminishing $[10,11]$. At the same time choroidal neovascular membranes associated with AMD include macrophages [12], which may respond to statins. The association between the use of statins and age-related macular degeneration has been evaluated in many clinical studies; however the results have been contradictory [13]. The likely explanation is an absence of universal approach: for eligibility criteria including types of AMD, type of statin, dosage, duration of treatment. The latest encouraging research conducted by Varvas et al. [14] for the first time evidenced the efficacy of high dose atorvastatin therapy in AMD patients with high-risk features for progression presented by regress of druses and corresponding increase of visual acuity. Taken into account that not all statins are equally effective, the challenge for future research will be to determine the best type and dosage of statins and to discover a treatment algorhytm. Currently available findings suggest that cardiovascular diseases and AMD share similarities in their pathogenesis, highlighting an importance of cardiovascular disease risk factors management intended also simultaneously to lower AMD morbidity and improve the quality of life of aging population.

\section{References}

1. www.drugs.com

2. Mihos CG, Santana O (2011) Pleiotropic effects of the HMG-CoA reductase inhibitors. Int J Gen Med 4: 261-271.

3. Li JJ, Chen MZ, Chen X, Fang CH (2003) Rapid effects on lipid profile and C-reactive protein by simvastatin in patients with hypercholesterolemia. Clin Cardiol 26(10): 472-476.

4. Ostadal P, Alan D, Hajek P, Horak D, Vejvoda J, et al. (2003) The effect of early treatment by cerivastatin on the serum level of C-reactive protein, interleukin-6, and interleukin-8 in the patients with unstable angina and non-Q-wave myocardial infarction. Mol Cell Biochem 246(1-2): 45-50.

5. Fischer T (2009) A new possible strategy of prevention and preventive treatment of age-related macular degeneration resting on recent clinical and pathophysiological observations. Orv Hetil 150(11): 503512 .

6. Fischer $\mathrm{T}$ (2015) The age-related macular degeneration as a vascular disease/part of systemic vasculopathy: contributions to its pathogenesis. Orv Hetil 156(9): 358-365. 
7. Brown MM, Brown GC, Stein JD, Roth Z, Campanella J, et al. (2005) Age-related macular degeneration: economic burden and value-based medicine analysis. Can J Ophthalmol 40(3): 277-287.

8. Klein R, Chou C, Klein B, Zhang X, Mener SM, et al. (2011) Prevalence of Age Related Macular Degeneration in the US Population. Arch Ophthalmol 129(1): 75-80.

9. Donoso LA, Kim D, Frost A, Callahan A, Hageman G (2006) The role of inflammation in the pathogenesis of age-related degeneration. Surv Ophthalmol 51(2): 137-152.

10. Guymer RH, Chiu AW, Lim L, Baird PN (2005) HMG CoA reductase inhibitors (statins): do they have a role in age-related macular degeneration? Surv Ophthalmol 50(2): 194-206.

11. Guymer RH, Dimitrov PN, Varsamidis M, Lim LL, Baird PN, et al. (2008) Can HMG Co-A reductase inhibitors (statins) slow the progression of age-related macular degeneration? The age-related maculopathy statin study (ARMSS). Clin Interv Aging 3(3): 581-593.

12. Grossniklaus HE, Cingle KA, YoonYD, Ketkar N, L'Hernault N, et al (2000) Correlation of histologic 2-dimensional reconstructional and confocal scanning laser microscopic imaging of choroidal in eyes with age-related maculopathy. Arch Ophthalmol 118(5): 625-629.

13. Gehlbach P, Li T, Hatef E (2016) Statins for age-related macular degeneration. Cochrane Database Syst Rev (8): CD006927.

14. Vavvas DG, Daniels AB, Kapsala ZG, Goldfarb JW, Ganotakis E, et al. (2016) Regression of Some High-risk Features of Age-related Macular Degeneration (AMD) in Patients Receiving Intensive Statin Treatment. EBioMedicine 5: 198-203.

\section{Your next submission with Juniper Publishers will reach you the below assets}

- Quality Editorial service

- Swift Peer Review

- Reprints availability

- E-prints Service

- Manuscript Podcast for convenient understanding

- Global attainment for your research

- Manuscript accessibility in different formats

( Pdf, E-pub, Full Text, Audio)

- Unceasing customer service

Track the below URL for one-step submission https://juniperpublishers.com/online-submission.php 